\title{
Expectation-Performance Gap in Knowledge and Competencies in Accounting Graduates: Evidence from Tunisia
}

\author{
Souidi Khouloud* and Rajhi Mohamed Tahar
}

Faculty of Economic Sciences and Management of Tunis, Tunisia

$\begin{array}{ll}\text { ARTICLE INFO } & \text { ABSTRACT } \\ \begin{array}{l}\text { Keywords: } \\ \text { Accounting Education }\end{array} & \begin{array}{l}\text { The aim of this paper is to investigate the gap between the } \\ \text { competencies which employers expect and those acquired by } \\ \text { Tunisia }\end{array} \\ \begin{array}{l}\text { Expectation-Performance Gap } \\ \text { Knowledge and Competencies } \\ \text { of Accounting Graduates }\end{array} & \begin{array}{l}\text { \&Porter, 2010) to examine the causal factors that contributed } \\ \text { to this gap. A questionnaire survey was distributed to }\end{array} \\ \text { accounting professionals and educators. Furthermore, we } \\ \text { analyzed data collected by non-parametric tests: the Wilcoxon } \\ \text { signed-rank test and the Mann-Whitney test. Findings indicate } \\ \text { the constraints within universities as contributing to the failure } \\ \text { of accounting education to provide accounting graduates with } \\ \text { the competencies expected by accounting professionals. This } \\ \text { study contributes to the literature as one of few studies that } \\ \text { examine expectation-performance gap in Tunisia. }\end{array}$

\section{Introduction}

In recent decades, the business environment in which professional accountants are being operated, has been undergone major changes. These changes are mainly due to the emergence of information and communications technology, globalization and the concentration of institutional structure. (Albrecht \& Sack,2000). In this new business environment, employers generally expect a wide variety of skills from new accounting graduates (Kavanagh \&Drenan, 2008, Webb \& Chaffer, 2016). In this context, (klibi \& Oussi, 2013) find that accounting professionals expect accounting graduates to be equipped with organizational and business skills, personal skills, and interpersonal skills (IFAC, 1996). Moreover, the results of the study (Tan \& Fawzi, 2017) showed that the most sought skills included the ability to collaborate with colleagues, presenting, discussing and defending views, and having a positive attitude.

However, several researchers indicated that there is a gap between the knowledge and skills acquired by accounting graduates and those expected by accounting professionals. (Jackling \& De Lange, 2009, Kavanagh \& Drennan, 2008, Altrawneh, 2016). As a result, several studies indicate that accounting graduates are ill-equipped to begin professional practice (Albrecht \& Sack, 2000; Mohamed \& Lashine, 2003).

Like many countries, Tunisia faced such challenges in higher educational system.In 2005, Tunisia adopted the BMD system (Bachelor - Master - Doctorate)which aims to respond to the needs of the labor market. It should be noted that our study will focus on "Bachelor degree", which continues for a period of three years after the high school diploma.

Despite the reform of the higher educational system in Tunisia, the labor market still suffers from several constraints aggravated by the social and political events following the revolution of January14, 2011.The objective of this paper is to examinethe knowledge and skills

* Corresponding Author E-Mail Address: khouloud86souidi@gmail.com 
acquired by accounting graduates and those expected by chartered accountants "expectationperformance gap" in Tunisia. In particular, we will identify the causal factors contributing to this gap. Therefore, a questionnaire survey was distributed to chartered accountants who are registered on the board of the chartered accountants and accounting university educators.

This article is organized as follows: The second section presents an overview of the previous research work, the third section exposes the research hypothesis, the fourth section describes the methodology adopted and the fifth section presents the results obtained. The last section concludes this research.

\section{The review of literature}

Several studies, such as those conducted in Australia, have shown that there is a gap between the knowledge and skills acquired by accounting graduates and those expected by professional accountants (Courtis \& Zaid, 2002, Evans et al., 2010, Hancock et al 2009, Jackling \& De Lange, 2009, Kavanagh \& Drennan, 2008).

According to (Mohamed\&Lashine,2003) the gap between the skills acquired by graduates and those required by the labor market is mainly due to changes in the business environment and the reluctance to change the higher education system in accounting sciences (Albrecht \&Sack,2000). Most accounting education programs at universities in many countries lack skills training that are needed by accounting professionals (AAA, 1986; AECC, 1990; Albrecht \& Sack, 2000).

Searchers conducted by (Bui \& Porter, 2010) found that there is a gap between the skills required by professional accountants and those acquired by accounting graduates "expectation-performance gap" (Low et al, 2016; El-Dalahmeh, 2017). The authors identify the causal factors contributing to this gap such as: accounting students' ability and aptitude; institutional factors, pedagogical methods and content of university program.

The framework expectation-performance gap is adopted by (Abayadeera \& Watty, 2014), in the context of Sri Lanka. They found that accountants professionals are dissatisfied with the skills of accounting graduates such as: professional ethics, intellectual skills; decision making skills; problem solving skills; the ability to think critically; written and oral communication in English skills; and listening ability. Their study has also shown that university educators have admitted that they lack high confidence in teaching many generic skills.

\section{Formulation of hypotheses}

We have adopted (Bui \& Porter's, 2010) expectation-performance gap" framework to examine the gap between the knowledge and skills acquired by accounting graduates and those expected by chartered accountants. The authors discuss three causal factors contributing to this gap: Expectation gap, Constraints gap, Performance gap.

$\mathrm{H}_{1}$ : There is a gap between skills and knowledge acquired by accounting graduates and those expected by chartered accounting (expectation-performance gap).

$\mathrm{H}_{2}$ : There is a gap between the perception of accounting educators and chartered accountants in terms of knowledge and skills that should be acquired by accounting graduates. (Expectation gap).

$\mathrm{H}_{3}$ : There is a gap between the perception of accounting educators about the knowledge and skills that should be acquired by accounting graduates and those perceived as reasonably acquired. (Constraints gap).

$\mathrm{H}_{4}$ : There is a gap between the knowledge and skills that accounting educators perceived to be reasonably acquired by accounting graduates and those perceived as actually possess by chartered accountants. 


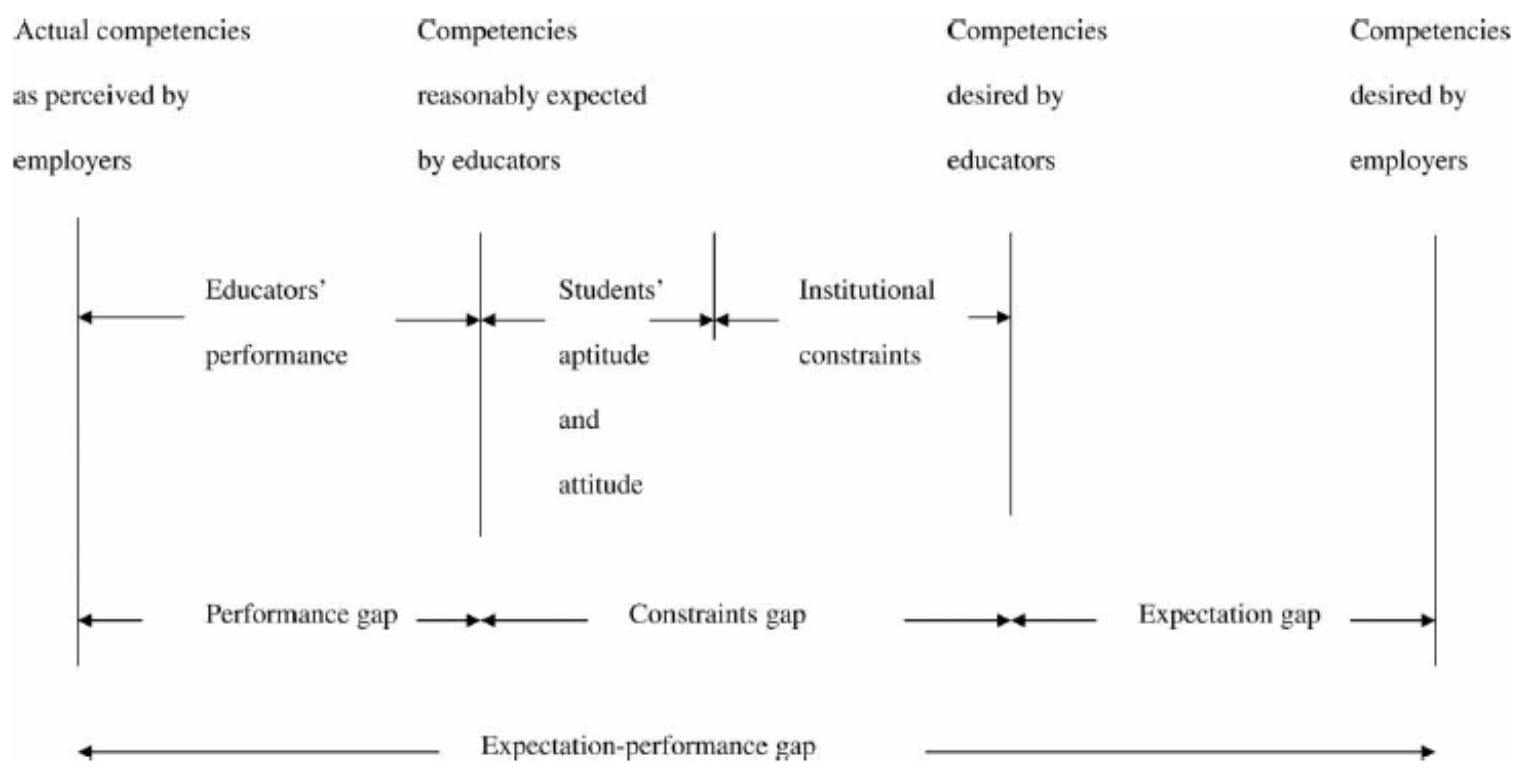

Figure 1. hypothesized structure of accounting education's expectation-performance gap (Source: Bui and Porter (2010) framework)

\section{Research Methodology}

\subsection{Data collection}

Data was collected by addressing questionnaire surveys to two groups: university educators and chartered accountants registered on the board of chartered accountants of Tunisia. Items for skills and knowledge were based on International Education Standards, (IES 2 and IES 3). This choice can be justified by the fact that these standards are recognized internationally, and they present the learning outcomes that accountants must achieve.

It should also be noted that this scale of measurement has been adopted in other research works. Several authors have attempted to determine the extent of compliance of the accounting program with international education standards such as (Watty et al, 2013). Other studies such as (Pratama,2015; Majzoub \& Aga, 2015), used this measure to identify perception differences between university educators and professional accountants about competencies of graduates. It should also be noted that we did not use the IES variable scale of the information technology knowledge because it fails to explain cultural differences. Adapted to our context, we made the choice to use the measurement scale of (Barac,2009).

In our research work, we focus more specifically on interpersonal and communication skills, and intellectual skills. This choice is justified by the fact that these skills are considered the most important for success in accounting profession. Several organizations emphasize the importance of interpersonal skills and communication; and intellectual skills in the workplace: for example (AECC, 1990, AAA, 1986, IFAC, 1996).

The first questionnaire was addressed to university educators. The questions are formulated on the following main topics: General information, "Expectation gap", "Constraints gap" and "Performance gap". The second questionnaire was addressed to chartered accountants which replicates questions addressed to university educators and excludes the question of the "constraints gap". It should be noted that we have adopted the Likert scale which is the most frequently used in surveys and usually comes in five choices $(1=$ not agree at all; to $5=$ strongly agree).

The questionnaire was administered on the one hand to 464 chartered accountant's governorate of Tunis and Ben Arous who represent the majority (we excluded chartered accountants who had less than ten years of experience. Indeed, their experience is recommended in order to better evaluate the knowledge and skills acquired by accounting 
graduates). On the other hand, the second questionnaire was distributed to 70 accounting university educators; Finally, our sample is composed of 98 chartered accountants and 66 university educators. This represents a response rate of $94.28 \%$ of university educators and $32.66 \%$ of chartered accountants.

\subsection{Statistical Analysis Method}

In order to measure the gap between the knowledge and skills acquired by accounting graduates and those expected by chartered accountants, we proceeded, first to the verification of the conditions of normality which is not achieved in our case. In fact, we used nonparametric tests to answer our research problem: the Mann Whitney test which aims to compare two independent samples and the Wilcoxon test which aims to compare two paired samples. Data from the questionnaires were analyzed using SPSS version 21 for Windows.

\section{Results}

\subsection{Expectation-performance gap}

The Wilicoxon test indicates that the sum of the positive ranks is nearly equals the sum of the negative ranks in management accounting, taxation, Spreadsheet software (Excel) and Standard internet software (e-mail, web browser) (see table 1). This test also indicates that the sum of the negative ranks is different from the sum of the positive ranks in financial accounting, audit, Finance and financial management, Professional values and ethics, economics, business environment, financial market, quantitative methods, accounting management, Management and strategic decision making., Database software (Access), Specific Search Tool, Business presentation software (PowerPoint), Word processing software (Word), Accounting packages (Pastel), Audit working paper-related software, Utility software (CAATS), Intellectual Skills and Interpersonal Skills and Communication.

Results have revealed that many of the skills are not achieved by accounting graduates at the level expected by chartered accounting. The gap between the knowledge and skills acquired by accounting graduates and those expected by accountants which really exists. Our results are in line with research conducted by (Abayadeera \& Watty, 2014). These authors noted that there is a gap between the skills and knowledge acquired by accounting graduates and those required by professional accountants. Besides, our results are consistent with the study conducted by (Bui \&Porter, 2010; Wells et al, 2009) in New Zealand and others (Tempone \& Martin, 2003, Kavanagh \& Drennan, 2008, Jackling \& De Lange, 2009) in Australia.

\subsection{Expectation gap}

The MannWhitney $U$ test indicates that there are significant differences between chartered accounting and university educators (see Table 2), which means that the respondent groups do not share similar views over such skills and knowledge. Indeed, the average rank of university educators is higher than the average rank of chartered accountants in financial accounting, taxation and audit. Nevertheless, the average rank of chartered accountants is higher than the average rank of university educators in economics, management accounting, business environment, quantitative methods, economics, Spreadsheet software (Excel), specific search tool, Word processing software (Word), and utility software (CAATS).

Results has shown that educators focus on accounting knowledge, while chartered accountants put the emphasis on organizational and business knowledge, as well as on information technology knowledge. The results of Mann-Whitney U-test indicate that the respondent groups have similar views on the importance of intellectual and interpersonal and communication skills.

Despite these findings, there is a difference in perception between university educators and chartered accountants about knowledge and skills needed for accounting graduates, that is 
consistent with the research work done by (Mohdali et al. 2016, Armitage,1991, Novin et al. 1997, Theuri \& Gunn,1999, Francis \&Minchington, 1999).

\subsection{Constraints gap}

The Wilicoxon test indicates that the sum of the negative ranks is different from the sum of the positive ranks about financial accounting, Taxation, Business and commercial law, Audit and assurance, Finance and financial management, Professional values and ethics, economics, business environment, quantitative methods, Management and strategic decision making, technology knowledge, interpersonal and communication skills, and intellectual skills (see Table 3). Thus, results have revealed that there is a gap between the perception of accounting educators about the knowledge and skills should be acquired by accounting graduates and those perceived as reasonably acquired. This conclusion is corroborated by the research conducted by (Abayadeera \&Watty, 2014; Bui \& Porter, 2010). Indeed, this gap is due to a number of constraints.

Table 4.

Obstacles to develop skills and knowledge at university

Crowded classes 3.72

The lack of financial, human and material resources 3.37

Students have an inappropriate attitude to learn $\quad 2.36$

Students have an inappropriate intellectual ability $\quad 2.87$

According to table 4 this gap is due to crowded classes, tenure and promotion policies of universities, the lack of financial, human and material resources, the aptitude and the attitude of the students. In the Tunisian context, accounting educators believe that crowded classes inhibit them to develop skills and knowledge needed by the labor market.

\subsection{Performance gap}

The Mann Whitney U test indicates that there are significant differences between the two groups in financial accounting, Professional values and ethics, management accounting, specific research tool, audit working paper-related software, negotiate acceptable solutions and agreements in professional situations, Spreadsheet software (Excel), Standard internet software (e-mail, web browser), Business presentation software (PowerPoint), utility software (CAATS, interpersonal and communication skills (see Table 5). Results have revealed that there is a gap between the knowledge and skills that accounting educators perceived to be reasonably acquired by accounting graduates and those perceived as actual possess by chartered accountants.

This conclusion is corroborated by the research conducted (Abayadeera \& Watty,2014) and (Bui \& Porter,2010). Indeed, this gap reveals the failings of pedagogy methods and the content of the program. It proves that universities in the Tunisian context are devoided of innovations and suffer from a lack of interest in adopting new teaching methods. It also appears that accounting higher education programs don't meet the expectations of the labor market.

\section{Conclusion}

This article aims to examine the gap between knowledge and skills acquired by accounting graduates and those required by chartered accountants. To achieve this goal, we adapt the framework of (Bui \&Porter, 2010) expectation-performance gap, and it was amended to suit the Tunisian context. A questionnaire was administered to chartered accountants and 
university educators. Data collected by the questionnaire was analysed by non-parametric test, namely the Mann whitney test and the Wilicoxon test.

Our results has shown that there is a gap between knowledge and skills acquired by accounting graduates and those expected by chartered accounting. The results have also revealed that chartered accounting put emphasis on the importance of organizational and business knowledge as well as information technology knowledge. However, the university educators focus on accounting knowledge. In addition, our study proves that crowded classes is the main factor to empede accounting educators to develop skills required by the labor market.Accounting higher education programs seems unable to provide "job ready" for accounting graduates.

Like all researches, our study has a limit when it comes to providing samples: We were restricted to the perception of chartered accountants and university educators. It will be more interesting to share the study with the responsible parts for developing the content of the program of the Ministry of Higher Education, accountants enrolled in the company of Tunisian accountants and internal auditors registered in the Internal Audit Tunisian Association.

\section{References}

AAA (American Accounting Association). (1986), Future Accounting education: preparing for the profession (The special report of the AAA Committee on the future structure, content, and scope of Accounting Education - Bedford Report). Issues in Accounting Education, vol.1, n 1, pp.168-195.

Abayadeera,N.Watty,K.(2014), The expectation-performance gap in generic skills in accounting graduates: Evidence from Sri Lanka,Asian Review of Accounting, vol. 22, n 1, pp $56-72$.

Accounting Education Change Commission (AECC). (1990), Objectives of education for accountants: Position Statement Number One. Issues in Accounting Education, vol.5, n 2, pp. 307-312.

Armitage, J. L. (1991), Academics' and practitioners' views on the content and importance of the advanced financial accounting course, Journal of Accounting Education, vol.9, n 2, pp. $327-340$.

Albrecht, W. S. Sack, R. J. (2000), Accounting education: Charting the course through a perilous future, American Accounting Association. Accounting Education Series, vol. 16, pp. 21-30.

Altarawneh,G,A.(2016), An Empirical Evaluation of Accounting Graduates' Employability Skills from Jordanian Employers' Perspective. International Business Research, vol. 9, n1.

Barac, K. (2009), South African training officers' perceptions of the knowledge and skillsrequirements of entry-level training accountants. Meditari Accountancy Research, vol. 17. n 2, pp 19-46.

Bui, B. Porter, B. (2010), Expectation-Performance Gap in Accounting Education: An Exploratory Study, Accounting Education: An International Journal, vol. 19, n 1, pp. 2350 .

Courtis, J. K. Zaid, O. (2002), A early employment problems of Australian accounting graduates: An exploratory study. Accounting Forum, vol.26, n 3, pp. 321-339. 
EL-dalahmeh, S. M.(2017), Information Technology (IT)Competencies Desired in New Accounting Graduates: A Survey in Jordanian Business Environment, International Journal of Business and Management, vol. 12 n 5.

Evans, E. Burritt, R. and Guthrie, J. (Eds) (2010) Institute of Chartered Accountants in Australia (ICAA) (2010), Accounting Education at a Crossroad in 2010 (Sydney: Centre for Accounting, Governance and Sustainability, University of South Australia, Institute of Chartered Accountants in Australia).

Francis, G.Minchington, C. (1999), Quantitative skills: Is there an expectation gap between the education and practice of management accountants? Accounting Education: an international journal, vol.8, n 4, pp. 301-319.

Hakim,R.R.C.(2016), Are Accounting Graduates Prepared For Their Careers? A Comparison of Employees' and Employers' Perceptions, Global Review of Accounting and Finance, vol. 7, n. 2 .

Hancock, P. Howieson, B. Kavanagh, M. Kent, J.Tempone, I. Segal, N. and Freeman, M. (2009), The roles of some key stakeholders in the future of accounting education in Australia,Australian Accounting Review,vol. 19, n 3, pp.249-260.

International Accounting Education Standards Board, (2014). Handbook of international education pronouncements 2014 edition.

International Federation Of Accountants (IFAC),(1996). Prequalification education assessement of professionals competences and experiences requirements of professionals accounting international education guideline $\mathrm{n} 9$ Washington IFAC.

Jackling, B. De Lange, P. (2009), Do accounting graduates' skills meet the expectations of employers? A matter of convergence or divergence", Accounting Education, vol. 18, n 4/5, pp. 369-385.

Kavanagh, M. H.Drenan, L. (2008). What skills and attributes does an accounting graduate need? Evidence from student perceptions and employer expectations. Accounting and Finance, vol. 48, pp. 279-300.

Klibi,M,F.Oussi, A.A. (2013), Skills and attributes needed for success in accounting career: do employers' expectations fit with students' perceptions? Evidence from Tunisia', International journal of business and management, vol. 8, n 8, pp.118-132.

Low,M.Botes, V.Dela Rue, D. and Allen, J. (2016), Accounting Employers' Expectations The Ideal Accounting Graduates. e-Journal of Business Education \& Scholarship of Teaching, vol. 10, n. 1, pp.36-57.

Majzoub, S.Aga,M. (2015), Characterizing the Gap between Accounting Education and Practice: Evidence from Lebanon,International Journal of Business and Management, vol. $10, \mathrm{n} 12$.

Mathews, M. R.(2004), Accounting curricula: Does professional accreditation lead to uniformity within Australian bachelor's degree programmes? Accounting Education, vol.13, n 1, pp. 1-71.

Mohali,I.,Kamarudin, K. Suriani,N,A. Saad,N.Z. and Afandi,Z,A,M.(2016) Perception of employers and educators in accounting education. Procedia economics and finance, vol.35, pp. 54-63.

Mohamed, E. K., Lashine, S. H. (2003), Accounting knowledge and skills and the challenges of a global business environment. Managerial Finance, vol.29, pp.3-16. 
Novin, A. M. Fetyko, D. F. and Tucker, J. M. (1997), Perceptions of accounting educators and public accounting practitioners on the composition of 150-hour accounting programs: A comparison, Issues in Accounting Education, vol.2, n 2, pp. 331-352.

Pratama,A. (2015), Bridging the gap between academicians and practitioners on accountant competencies: An analysis of international education standards (IES)implementation on Indonesia's. Accounting Education, vol. 211, n 25, pp. 19-26.

Tan, L.M, Fawzi, L. (2017), Employability skills required of accountants. 17th Annual Conference of the Asian Academic Accounting Association (2016 Four A Conference) Kuching, Sarawak.

Tempone, I. Martin, E. (2003), Iteration between theory and practice as a pathway to developing generic skills in accounting. Accounting Education, vol. 12, n 3, pp.227-244.

Theuri, P. M.,Gunn, R. (1998), Accounting information systems course structure and employer systems skills expectations, Journal of Accounting Education, vol.16, n 1, pp. 101-121.

Watty, K.,Sugahara, S., Abayadeera, N. and Perera, L. (2013), Developing a Global Model of Accounting Education and Examining IES Compliance in Australia, Japan, and Sri Lanka, Journal accounting education_vol. 22, n 5.

Webb, J. Chaffer, C. (2016), The expectation performance gap in accounting education: a review of generic skills development in UK accounting degrees. Journal Accounting Education, vol. 25, n 4 .

Wells, P. Gebric, P. Kranenburg, I. and Bygrave, J. (2009), Professional Skills and Capabilities of Accounting Graduates: The New Zealand Expectation Gap? Accounting Education: An International Journal, vol.18, n .4/5. 
Table 1.

Chartered accountant responses on the knowledge and skills acquired by accounting graduates and those expected. (expectation-performance gap)

\begin{tabular}{|c|c|c|c|c|}
\hline Items & Rank & $\begin{array}{l}\text { Mean } \\
\text { rank }\end{array}$ & Rank sum & $\mathrm{z}$ \\
\hline \multirow{2}{*}{ Financial accounting } & Negative ranks & 20 & 300,5 & \multirow{2}{*}{$3,694 * *$} \\
\hline & Positive ranks & 29 & $1.077,5$ & \\
\hline \multirow{2}{*}{ Management accounting } & Negative ranks & 22 & 438 & \multirow{2}{*}{0,737} \\
\hline & Positive ranks & 18 & 342 & \\
\hline \multirow{2}{*}{ Taxation } & Negative ranks & 26 & 675 & \multirow{2}{*}{0,412} \\
\hline & Positive ranks & 25 & 600 & \\
\hline \multirow{2}{*}{ Business and commercial law } & Negative ranks & 28 & 1.359 & \multirow{2}{*}{$5,937 * *$} \\
\hline & Positive ranks & 18 & 72 & \\
\hline \multirow{2}{*}{ Audit and assurance } & Negative ranks & 29 & 1.565 & \multirow{2}{*}{$6,433 * *$} \\
\hline & Positive ranks & 15,5 & 31 & \\
\hline \multirow{2}{*}{ Finance and financial management } & Negative ranks & 30 & 1.689 & \multirow{2}{*}{$6,804 * *$} \\
\hline & Positive ranks & 22 & 22 & \\
\hline \multirow{2}{*}{ Professional values and ethics } & Negative ranks & 38 & 2.446 & \multirow{2}{*}{$6,239 * *$} \\
\hline & Positive ranks & 32 & 255 & \\
\hline \multirow{2}{*}{ Economics } & Negative ranks & 39 & 2.863 & \multirow{2}{*}{$7,425 * *$} \\
\hline & Positive ranks & 21 & 63 & \\
\hline \multirow{2}{*}{ Business environment } & Negative ranks & 41 & 3.321 & \multirow{2}{*}{$7,957 * *$} \\
\hline & Positive ranks & 0 & 0 & \\
\hline \multirow{2}{*}{ Financial markets } & Negative ranks & 31 & 1.124 & \multirow{2}{*}{$3,121 *$} \\
\hline & Positive ranks & 22 & 416 & \\
\hline \multirow{2}{*}{ Quantitative methods } & Negative ranks & 34 & $2.193,5$ & \multirow{2}{*}{$7,093 * *$} \\
\hline & Positive ranks & 17,5 & 17,5 & \\
\hline Management & Negative ranks & 34,5 & 2.346 & $7300 * *$ \\
\hline Management & Positive ranks & 0 & 0 & $1,390^{* *}$ \\
\hline Management and strategic decision & Negative ranks & 38,5 & 2.926 & $7858 * *$ \\
\hline making & Positive ranks & 0 & 0 & $7,858^{* *}$ \\
\hline Snreadsheet software (Fxcel) & Negative ranks & 23 & 411 & 0560 \\
\hline Spreadsheet software (Excel) & Positive ranks & 20,5 & 492 & 0,569 \\
\hline & Negative ranks & 33,5 & 2.108 & \\
\hline Database software (Access) & Positive ranks & 18,5 & 37 & $6,951^{* *}$ \\
\hline Standard internet software (e-mail, web & Negative ranks & 26,5 & 636 & 0555 \\
\hline browser) & Positive ranks & 26,5 & 742 & 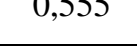 \\
\hline Specific research tool (Research & Negative ranks & 34,5 & 2.346 & \\
\hline toolbox) & Positive ranks & 0 & 0 & $1,461+\cdots$ \\
\hline Business presentation software & Negative ranks & 33 & 2.145 & $7138 * *$ \\
\hline (PowerPoint) & Positive ranks & 0 & 0 & $1,438^{\cdots}$ \\
\hline Audit working naner-related software & Negative ranks & 43 & 3.655 & $8258 * *$ \\
\hline Audit working paper-related soltware & Positive ranks & 0 & 0 & 8,25 \\
\hline Word prococing oftwore (Word) & Negative ranks & 41 & 3.208 & Q $124 * *$ \\
\hline Word processing soltware (word) & Positive ranks & 32 & 32 & $8,124 \cdots$ \\
\hline & Negative ranks & 43 & 3.655 & \\
\hline Accounting packages (Pastel) & Positive ranks & 0 & 0 & $8,200^{* *}$ \\
\hline & Negative ranks & 43 & 3.655 & \\
\hline Utility software (CAAIS) & Positive ranks & 0 & 0 & $8,223 \cdots$ \\
\hline The ability to locate, obtain, organize & Negative ranks & 41 & 3321 & \\
\hline $\begin{array}{l}\text { and understand } \\
\text { information from human, print and } \\
\text { electronic sources. }\end{array}$ & Positive ranks & 0 & 0 & $7,969 * *$ \\
\hline The capacity for inquiry, research, & Negative ranks & 46,06 & 3961,5 & \\
\hline $\begin{array}{l}\text { logical and analyticalthinking, powers of } \\
\text { reasoning, and critical analysis. }\end{array}$ & Positive ranks & 14,5 & 43,5 & $8,156^{* *}$ \\
\hline The ability to identify and solve & Negative ranks & 45,56 & 3872,5 & $8,075 * *$ \\
\hline
\end{tabular}




\begin{tabular}{|c|c|c|c|c|}
\hline $\begin{array}{l}\text { unstructured problemswhich may be in } \\
\text { unfamiliar settings. }\end{array}$ & Positive ranks & 14,5 & 43,5 & \\
\hline \multirow{2}{*}{$\begin{array}{l}\text { Work with others in a consultative } \\
\text { process, to withstandand resolve } \\
\text { conflict. }\end{array}$} & Negative ranks & 49,58 & 4611 & \multirow{2}{*}{$8,484 * *$} \\
\hline & Positive ranks & 15 & 45 & \\
\hline \multirow{2}{*}{ Work in teams. } & Negative ranks & 49,58 & 4462,5 & \multirow{2}{*}{$8,264 * *$} \\
\hline & Positive ranks & 19,5 & 97,5 & \\
\hline \multirow{2}{*}{$\begin{array}{l}\text { Interact with culturally and intellectually } \\
\text { diverse people. }\end{array}$} & Negative ranks & 49,91 & 4691,5 & \multirow{2}{*}{$8,454 * *$} \\
\hline & Positive ranks & 20,5 & 61,5 & \\
\hline \multirow{2}{*}{$\begin{array}{l}\text { Negotiate acceptable solutions and } \\
\text { agreements in } \\
\text { professional situations. }\end{array}$} & Negative ranks & 47,5 & 4465 & \multirow[b]{2}{*}{$8,621 * *$} \\
\hline & Positive ranks & 0 & 0 & \\
\hline \multirow{2}{*}{$\begin{array}{l}\text { Work effectively in a cross-cultural } \\
\text { setting. }\end{array}$} & Negative ranks & 42,5 & 3570 & \multirow{2}{*}{$7,421 * *$} \\
\hline & Positive ranks & 85,5 & 171 & \\
\hline \multirow{3}{*}{$\begin{array}{l}\text { Present, discuss, report and defend } \\
\text { views effectivelythrough formal, } \\
\text { informal, written and spoken } \\
\text { communication. }\end{array}$} & Negative ranks & 45,5 & 4095 & \multirow{3}{*}{$8,345^{* *}$} \\
\hline & Positive ranks & 0 & 0 & \\
\hline & Positive ranks & 0 & 0 & \\
\hline
\end{tabular}


Table 2.

Group responses on expected knowledge and skills for accounting graduates (expectation gap)

\begin{tabular}{|c|c|c|c|c|}
\hline Items & Statuts & Mean rank & Rank sum & $\mathrm{Z}$ \\
\hline \multirow{2}{*}{ Financial accounting } & Chartered accountants & 65,35 & 6.404 & \multirow{2}{*}{$6,437 * *$} \\
\hline & Educators & 107,97 & 7.126 & \\
\hline \multirow{2}{*}{ Management accounting } & Chartered accountants & 81,86 & 8.022 & \multirow{2}{*}{0,247} \\
\hline & Educators & 83,45 & 5.508 & \\
\hline \multirow{2}{*}{ Taxation } & Chartered accountants & 74,86 & 7.336 & \multirow{2}{*}{$3,071 *$} \\
\hline & Educators & 93,85 & 6.194 & \\
\hline \multirow{2}{*}{ Business and commercial law } & Chartered accountants & 79,56 & 7.797 & \multirow{2}{*}{1,176} \\
\hline & Educators & 86,86 & 5.733 & \\
\hline \multirow{2}{*}{ Audit and assurance } & Chartered accountants & 75,68 & 7.417 & \multirow{2}{*}{$3,009 *$} \\
\hline & Educators & 92,62 & 6.113 & \\
\hline \multirow{2}{*}{ Finance and financial management } & Chartered accountants & 84,51 & 8.282 & \multirow{2}{*}{0,756} \\
\hline & Educators & 79,52 & 5.248 & \\
\hline \multirow{2}{*}{ Professional values and ethics } & Chartered accountants & 79,81 & $7.821,5$ & \multirow{2}{*}{1,024} \\
\hline & Educators & 86,49 & $5.708,5$ & \\
\hline \multirow{2}{*}{ Economics } & Chartered accountants & 89,29 & 8.750 & \multirow{2}{*}{$2,451 *$} \\
\hline & Educators & 72,42 & 4.780 & \\
\hline \multirow{2}{*}{ Business environment } & Chartered accountants & 93,97 & $9.209,5$ & \multirow{2}{*}{$4,270 * *$} \\
\hline & Educators & 65,46 & $4.320,5$ & \\
\hline \multirow{2}{*}{ Financial markets } & Chartered accountants & 90,55 & $8.873,5$ & \multirow{2}{*}{$2,99 *$} \\
\hline & Educators & 70,55 & $4.656,5$ & \\
\hline \multirow{2}{*}{ Quantitative methods } & Chartered accountants & 88,79 & $8.701,5$ & \multirow{2}{*}{$2,207 *$} \\
\hline & Educators & 73,16 & $4.828,5$ & \\
\hline Manorement & Chartered accountants & 90,94 & $8.912,5$ & \\
\hline Management & Educators & 69,96 & $4.617,5$ & $3,114^{*}$ \\
\hline Management and strategic decision & Chartered accountants & 85,76 & 8.404 & \\
\hline making & Educators & 77,67 & 5.126 & 1,246 \\
\hline & Chartered accountants & 91,76 & 8.992 & \\
\hline Spreadsheet software (Excel) & Educators & 68,76 & 4.538 & $3,452^{*}$ \\
\hline & Chartered accountants & 86,41 & 8.468 & \\
\hline Database software (Access) & Educators & 76,7 & 5.062 & 1,429 \\
\hline Standard internet software (e-mail, & Chartered accountants & 85,64 & 8.393 & \\
\hline web browser) & Educators & 77,83 & 5.137 & 1,193 \\
\hline Specific research tool (Research & Chartered accountants & 92,91 & 9.105 & $3828 * *$ \\
\hline toolbox) & Educators & 67,05 & 4.425 & $3,828 \cdots$ \\
\hline Business presentation software & Chartered accountants & 86,29 & 8.456 & \\
\hline (PowerPoint) & Educators & 76,88 & 5.074 & 1,386 \\
\hline Audit working paper-related & Chartered accountants & 79,56 & 7.797 & \\
\hline software & Educators & 86,86 & 5.733 & 1,241 \\
\hline Word nrocering stwore (Word) & Chartered accountants & 88,9 & 8.712 & \\
\hline Word processing software (Word) & Educators & 73 & 4.818 & $2,452 *$ \\
\hline & Chartered accountants & 84,72 & 8.303 & \\
\hline Accounting packages (Pastel) & Educators & 79,2 & 5.227 & 0,883 \\
\hline & Chartered accountants & 89,25 & $8.746,5$ & $2560 *$ \\
\hline Utility software (CAATS) & Educators & 72,48 & $4.783,5$ & $2,568 *$ \\
\hline The ability to locate, obtain, & Chartered accountants & 83,56 & 7946,50 & \\
\hline $\begin{array}{l}\text { organize } \\
\text { understandinformation }\end{array} \begin{array}{r}\text { and } \\
\text { from } \\
\text { human, print and electronic } \\
\text { sources. }\end{array}$ & Educators & 77,19 & 5094,50 & 1,010 \\
\hline The capacity for inquiry, research, & Chartered accountants & 82,18 & 8054,00 & \\
\hline $\begin{array}{l}\text { logical and analytical thinking, } \\
\text { powers of reasoning, and critical } \\
\text { analysis. }\end{array}$ & Educators & 82,97 & 5476,00 & 0,121 \\
\hline
\end{tabular}




\begin{tabular}{|c|c|c|c|c|}
\hline \multirow{2}{*}{$\begin{array}{l}\text { The ability to identify and solve } \\
\text { unstructured problems which may } \\
\text { be in unfamiliar settings. }\end{array}$} & Chartered accountants & 82,36 & 8071,00 & \multirow{2}{*}{0,054} \\
\hline & Educators & 82,71 & 5459,00 & \\
\hline \multirow{2}{*}{$\begin{array}{l}\text { Work with others in a consultative } \\
\text { process, to withstand and resolve } \\
\text { conflict. }\end{array}$} & Chartered accountants & 84,79 & 8309,00 & \multirow[b]{2}{*}{0,877} \\
\hline & Educators & 79,11 & 5221,00 & \\
\hline \multirow{2}{*}{ Work in teams. } & Chartered accountants & 79,20 & 7762,00 & \multirow{2}{*}{1,313} \\
\hline & Educators & 87,39 & 5768,00 & \\
\hline \multirow{2}{*}{$\begin{array}{l}\text { Interact with culturally and } \\
\text { intellectually diverse people. }\end{array}$} & Chartered accountants & 79,55 & 7796,00 & \multirow{2}{*}{1,209} \\
\hline & Educators & 86,88 & 5734,00 & \\
\hline \multirow{2}{*}{$\begin{array}{l}\text { Negotiate acceptable solutions and } \\
\text { agreements in } \\
\text { professional situations. }\end{array}$} & Chartered accountants & 85,29 & 8358,00 & \multirow[b]{2}{*}{1,079} \\
\hline & Educators & 78,36 & 5172,00 & \\
\hline \multirow{2}{*}{$\begin{array}{l}\text { Work effectively in a cross-cultural } \\
\text { setting. }\end{array}$} & Chartered accountants & 81,79 & 8015,00 & \multirow{2}{*}{0,279} \\
\hline & Educators & 83,56 & 5515,00 & \\
\hline \multirow{2}{*}{$\begin{array}{l}\text { Present, discuss, report and defend } \\
\text { views effectively through formal, } \\
\text { informal, written and spoken } \\
\text { communication. }\end{array}$} & Chartered accountants & 77,90 & 7634,00 & \multirow[b]{2}{*}{1,520} \\
\hline & Educators & 87,02 & 5569,00 & \\
\hline
\end{tabular}


Table 3.

Educators responses perception of the knowledge and skills should be acquired by accounting graduates and those perceived as reasonably acquired. (Constraints gap)

\begin{tabular}{|c|c|c|c|c|}
\hline Items & Rank & Mean rank & Rank sum & $\mathrm{Z}$ \\
\hline \multirow{2}{*}{ Financial accounting } & Negative ranks & 12,5 & 250 & \multirow{2}{*}{$3,266 *$} \\
\hline & Positive ranks & 12,5 & 50 & \\
\hline \multirow{2}{*}{ Management accounting } & Negative ranks & 15 & 240 & \multirow{2}{*}{0,577} \\
\hline & Positive ranks & 15 & 195 & \\
\hline \multirow{2}{*}{ Taxation } & Negative ranks & 12,9 & 245 & \multirow{2}{*}{$2,957 *$} \\
\hline & Positive ranks & 11 & 55 & \\
\hline \multirow{2}{*}{ Business and commercial law } & Negative ranks & 21,5 & 903 & \multirow{2}{*}{$6,016^{* *}$} \\
\hline & Positive ranks & 0 & 0 & \\
\hline \multirow{2}{*}{ Audit and assurance } & Negative ranks & 25,5 & 1.275 & \multirow{2}{*}{$6,459 * *$} \\
\hline & Positive ranks & 0 & 0 & \\
\hline \multirow{2}{*}{ Finance and financial management } & Negative ranks & 27 & 1.303 & \multirow{2}{*}{$6,264 * *$} \\
\hline & Positive ranks & 25 & 75 & \\
\hline \multirow{2}{*}{ Professional values and ethics } & Negative ranks & 25,5 & 1,275 & \multirow{2}{*}{$6,273 * *$} \\
\hline & Positive ranks & 0 & 0 & \\
\hline \multirow{2}{*}{ Economics } & Negative ranks & 16,5 & 528 & \multirow{2}{*}{$5,027 * *$} \\
\hline & Positive ranks & 0 & 0 & \\
\hline \multirow{2}{*}{ Business environment } & Negative ranks & 20,5 & 820 & \multirow{2}{*}{$5,655 * *$} \\
\hline & Positive ranks & 0 & 0 & \\
\hline \multirow{2}{*}{ Financial markets } & Negative ranks & 22 & 462 & \multirow{2}{*}{1,066} \\
\hline & Positive ranks & 18 & 318 & \\
\hline \multirow{2}{*}{ Quantitative methods } & Negative ranks & 26 & 1,234 & $6043 * *$ \\
\hline & Positive ranks & 16 & 32 & $0,043 * \cdots$ \\
\hline & Negative ranks & 27 & 671 & \\
\hline Management & Positive ranks & 24 & 605 & 0,331 \\
\hline Management and strategic decision & Negative ranks & 25 & 1,225 & \\
\hline making & Positive ranks & 0 & 0 & $0,255 \cdots$ \\
\hline Snreadsheet software (Fycel) & Negative ranks & 19 & 591 & \\
\hline spreadsneet soltware (Excel) & Positive ranks & 15 & 75 & $4,335 \cdots$ \\
\hline & Negative ranks & 25 & 958 & \\
\hline Database software (Access) & Positive ranks & 11 & 77 & $5,055 * \cdots$ \\
\hline Standard internet software (e-mail, & Negative ranks & 15 & 370 & \\
\hline web browser) & Positive ranks & 12 & 36 & $4,081^{* *}$ \\
\hline Specific research tool (Research & Negative ranks & 23 & 913 & \\
\hline toolbox) & Positive ranks & 11 & 33 & $5,414^{* \cdots}$ \\
\hline Business presentation software & Negative ranks & 24,5 & 1,029 & $5457 * *$ \\
\hline (PowerPoint) & Positive ranks & 13 & 52 & $5,45 / \cdots$ \\
\hline 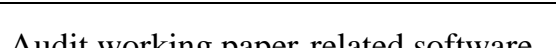 & Negative ranks & 25 & 1,225 & $6278 * *$ \\
\hline Audit working paper-related software & Positive ranks & 0 & 0 & $6,2 / 8 \cdots$ \\
\hline Word procescing software (Word) & Negative ranks & 21,5 & 622 & $3112 * *$ \\
\hline Word processing software (word) & Positive ranks & 18 & 198 & $3,112 \cdots$ \\
\hline & Negative ranks & 33,5 & 2,211 & \\
\hline Accountıng packages (Pastel) & Positive ranks & 0 & 0 & $7,173 * \cdots$ \\
\hline Utilitu cftwore $(C \wedge \wedge T C)$ & Negative ranks & 31 & 1,891 & $6000 * *$ \\
\hline Ut1lity software (CAATS) & Positive ranks & 0 & 0 & $6,900 * \cdots$ \\
\hline The ability to locate, obtain, organize & Negative ranks & 29 & 1653 & \\
\hline $\begin{array}{l}\text { and understand } \\
\text { information from human, print and } \\
\text { electronic sources. }\end{array}$ & Positive ranks & 0 & 0 & $6,706 * *$ \\
\hline The capacity for inquiry, research, & Negative ranks & 30,5 & 1830 & \\
\hline $\begin{array}{l}\text { logical and analyticalthinking, powers } \\
\text { of reasoning, and critical analysis. }\end{array}$ & Positive ranks & 0 & 0 & $6,832 * *$ \\
\hline The ability to identify and solve & Negative ranks & 32,5 & 2080 & $7082 * *$ \\
\hline unstructured problemswhich may be in & Positive ranks & 0 & 0 & $1,083 * *$ \\
\hline
\end{tabular}




\begin{tabular}{|c|c|c|c|c|}
\hline unfamiliar settings. & & & & \\
\hline \multirow{2}{*}{$\begin{array}{l}\text { Work with others in a consultative } \\
\text { process, to withstandand resolve } \\
\text { conflict. }\end{array}$} & Negative ranks & 30,5 & 1830 & \multirow{2}{*}{$6,839 * *$} \\
\hline & Positive ranks & 0 & 0 & \\
\hline \multirow{2}{*}{ Work in teams. } & Negative ranks & 33,5 & 2211 & \multirow{2}{*}{$7,257 * *$} \\
\hline & Positive ranks & 0 & 0 & \\
\hline \multirow{2}{*}{$\begin{array}{l}\text { Interact with culturally and } \\
\text { intellectually diverse people. }\end{array}$} & Negative ranks & 31,5 & 1953 & \multirow{2}{*}{$6,990 * *$} \\
\hline & Positive ranks & 0 & 0 & \\
\hline \multirow{2}{*}{$\begin{array}{l}\text { Negotiate acceptable solutions and } \\
\text { agreements in } \\
\text { professional situations. }\end{array}$} & Negative ranks & 27 & 1431 & \multirow{2}{*}{$6,448 * *$} \\
\hline & Positive ranks & 0 & 0 & \\
\hline \multirow{2}{*}{$\begin{array}{l}\text { Work effectively in a cross-cultural } \\
\text { setting. }\end{array}$} & Negative ranks & 29,5 & 1711 & \multirow{2}{*}{$6,739 * *$} \\
\hline & Positive ranks & 0 & 0 & \\
\hline \multirow{3}{*}{$\begin{array}{l}\text { Present, discuss, report and defend } \\
\text { views effectively through formal, } \\
\text { informal, written and spoken } \\
\text { communication. }\end{array}$} & Negative ranks & 32,5 & 2080 & \multirow{3}{*}{$7,033 * *$} \\
\hline & Positive ranks & 0 & 0 & \\
\hline & Positive ranks & 0 & 0 & \\
\hline
\end{tabular}


Table 5.

Group responses on the knowledge and skills that accounting educators perceived to be reasonably acquired by accounting graduates and those perceived as actual possess by chartered accountants (performance gap).

\begin{tabular}{|c|c|c|c|c|}
\hline Items & statuts & Mean rank & Rank sum & $\mathrm{Z}$ \\
\hline \multirow{2}{*}{ Financial accounting } & Chartered accountants & 77,38 & 7583,50 & \multirow{2}{*}{1,95} \\
\hline & Educators & 90,1 & 5946,50 & \\
\hline \multirow{2}{*}{ Management accounting } & Chartered accountants & 82,12 & 7966,00 & \multirow{2}{*}{0,05} \\
\hline & Educators & 81,82 & 5400,00 & \\
\hline \multirow{2}{*}{ Taxation } & Chartered accountants & 81,71 & 8007,50 & \multirow{2}{*}{0,3} \\
\hline & Educators & 83,67 & 5522,50 & \\
\hline \multirow{2}{*}{ Business and commercial law } & Chartered accountants & 84,62 & 8293,00 & \multirow{2}{*}{0,77} \\
\hline & Educators & 79,35 & 5237,00 & \\
\hline \multirow{2}{*}{ Audit and assurance } & Chartered accountants & 82,39 & 8074,00 & \multirow{2}{*}{0,04} \\
\hline & Educators & 82,67 & 5456,00 & \\
\hline \multirow{2}{*}{ Finance and financial management } & Chartered accountants & 83,25 & 7992,00 & \multirow{2}{*}{0,65} \\
\hline & Educators & 78,95 & 5211,00 & \\
\hline \multirow{2}{*}{ Professional values and ethics } & Chartered accountants & 88,16 & 8640,00 & \multirow{2}{*}{$1,97 * *$} \\
\hline & Educators & 74,09 & 4890,00 & \\
\hline \multirow{2}{*}{ Economics } & Chartered accountants & 81,19 & 7956,50 & \multirow{2}{*}{0,45} \\
\hline & Educators & 84,45 & 5573,50 & \\
\hline \multirow{2}{*}{ Business environment } & Chartered accountants & 83,77 & 8209,50 & \multirow{2}{*}{0,45} \\
\hline & Educators & 80,61 & 5320,50 & \\
\hline \multirow{2}{*}{ Financial markets } & Chartered accountants & 83,71 & 8204,00 & \multirow{2}{*}{0,44} \\
\hline & Educators & 80,7 & 5326,00 & \\
\hline \multirow{2}{*}{ Quantitative methods } & Chartered accountants & 85,91 & 8419,00 & \multirow{2}{*}{1,17} \\
\hline & Educators & 77,44 & 5111,00 & \\
\hline & Chartered accountants & 71,35 & 6992,00 & \\
\hline Management & Educators & 99,06 & 6538,00 & $3,83^{* *}$ \\
\hline Management and strategic decision & Chartered accountants & 86,3 & 8457,50 & 133 \\
\hline making & Educators & 76,86 & 5072,50 & 1,33 \\
\hline & Chartered accountants & 112,24 & 11000,00 & $103 * *$ \\
\hline Spreadsheet software (Excel) & Educators & 38,33 & 2530,00 & $10,3^{\cdots} \cdots$ \\
\hline Datahace software $(\Delta c c e c c)$ & Chartered accountants & 77,96 & $7.640,50$ & 162 \\
\hline Database sottware (Access) & Educators & 89,23 & 5889,50 & 1,02 \\
\hline Standard internet software (e-mail, web & Chartered accountants & 108,72 & 10655,00 & $072 * *$ \\
\hline browser) & Educators & 39,81 & 2548,00 & $9,12^{*}$ \\
\hline Specific research tool (Research & Chartered accountants & 74,57 & 7307,50 & $285 *$ \\
\hline toolbox) & Educators & 94,28 & 6222,50 & $2,85^{*}$ \\
\hline Business presentation $\quad$ software & Chartered accountants & 93,55 & 9168,00 & $301 * *$ \\
\hline (PowerPoint) & Educators & 66,09 & 4362,00 & $3,91 \cdots$ \\
\hline Audit working naner-related coftware & Chartered accountants & 85,31 & 8360,50 & 090 \\
\hline Audit working paper-related soltware & Educators & 78,33 & 5169,50 & 0,99 \\
\hline Word procescing software (Word) & Chartered accountants & 83,23 & 8156,50 & 027 \\
\hline Word processing soltware (word) & Educators & 81,42 & 5373,50 & 0,21 \\
\hline & Chartered accountants & 66,76 & 6542,00 & \\
\hline Accounting packages (Pastel) & Educators & 105,88 & 6988,00 & $5,45 \cdots$ \\
\hline Utility software (CAATS) & Chartered accountants & 98,34 & 9637,50 & \\
\hline Utillty soItware (CAAIS) & Educators & 58,98 & 3892,50 & $5,45^{\cdots}$ \\
\hline The ability to locate, obtain, organize & Chartered accountants & 86,83 & 8509,50 & \\
\hline $\begin{array}{l}\text { and understand } \\
\text { information from human, print and } \\
\text { electronic sources. }\end{array}$ & Educators & 76,07 & 5020,50 & 1,513 \\
\hline The capacity for inquiry, research, & Chartered accountants & 85,03 & 8332,50 & \\
\hline $\begin{array}{l}\text { logical and analytical thinking, powers } \\
\text { of reasoning, and critical analysis. }\end{array}$ & Educators & 78,75 & 5197,50 & 0,881 \\
\hline The ability to identify and solve & Chartered accountants & 82,31 & 8066,50 & 0,066 \\
\hline
\end{tabular}




\begin{tabular}{|c|c|c|c|c|}
\hline $\begin{array}{l}\text { unstructured problems which may be in } \\
\text { unfamiliar settings. }\end{array}$ & Educators & 82,78 & 5463,50 & \\
\hline \multirow{2}{*}{$\begin{array}{l}\text { Work with others in a consultative } \\
\text { process, to withstand and resolve } \\
\text { conflict. }\end{array}$} & Chartered accountants & 91,22 & 8939,50 & \multirow{2}{*}{$3,158 *$} \\
\hline & Educators & 69,55 & 4590,50 & \\
\hline \multirow{2}{*}{ Work in teams. } & Chartered accountants & 89,36 & 8757,50 & \multirow{2}{*}{$2,379 *$} \\
\hline & Educators & 72,31 & 4772,50 & \\
\hline \multirow{2}{*}{$\begin{array}{l}\text { Interact with culturally and } \\
\text { intellectually diverse people. }\end{array}$} & Chartered accountants & 75,95 & 7443,00 & \multirow{2}{*}{$2,257^{*}$} \\
\hline & Educators & 92,23 & 6087,00 & \\
\hline \multirow{2}{*}{$\begin{array}{l}\text { Negotiate acceptable solutions and } \\
\text { agreements inprofessional situations. }\end{array}$} & Chartered accountants & 71,66 & 7023,00 & \multirow{2}{*}{$3,825 * *$} \\
\hline & Educators & 98,59 & 6507,00 & \\
\hline \multirow{2}{*}{$\begin{array}{l}\text { Work effectively in a cross-cultural } \\
\text { setting. }\end{array}$} & Chartered accountants & 78,99 & 7267,50 & \multirow{2}{*}{0,176} \\
\hline & Educators & 80,20 & 5293,50 & \\
\hline \multirow{2}{*}{$\begin{array}{l}\text { Present, discuss, report and defend } \\
\text { views effectively through formal, } \\
\text { informal, written and spoken } \\
\text { communication. }\end{array}$} & Chartered accountants & 78,80 & 7722,00 & \multirow[b]{2}{*}{1,280} \\
\hline & Educators & 88,00 & 5808,00 & \\
\hline
\end{tabular}

